\title{
Reptiles of the municipality of Juiz de Fora, Minas Gerais state, Brazil
}

\author{
Bernadete Maria de Sousa ${ }^{1,2,5}$, Samuel Campos Gomides ${ }^{1,2}$, Alexandre de Assis Hudson ${ }^{1,3}$, \\ Leonardo Barros Ribeiro $^{4}$ \& Iara Alves Novelli ${ }^{2}$
}

\author{
${ }^{1}$ Programa de Pós-graduação em Ciências Biológicas, Comportamento e Biologia Animal, Instituto de \\ Ciências Biológicas, Universidade Federal de Juiz de Fora-UFJF, Campus Universitário, s/n, Martelos, \\ CEP 36036-900, Juiz de Fora, MG, Brazil \\ ${ }^{2}$ Laboratório de Herpetologia, Departamento de Zoologia, Instituto de Ciências Biológicas, \\ Universidade Federal de Juiz de Fora - UFJF, Campus Universitário, s/n, Martelos, \\ CEP 36036-900, Juiz de Fora, MG, Brazil \\ ${ }^{3}$ Instituto Chico Mendes de Conservação da Biodiversidade - ICMBio, Floresta Nacional de Ritápolis, \\ Rod. BR 494, Ritápolis, CP 77, CEP 36307-970, São João Del Rei, MG, Brazil \\ ${ }^{4}$ Colegiado de Ciências Biológicas, Universidade Federal do Vale do São Francisco - UNIVASF, \\ Campus Ciências Agrárias, Rod. BR 407, Km 12, Lote 543, CEP 56300-990, Petrolina, PE, Brazil \\ ${ }^{5}$ Corresponding author: Bernadete Maria de Sousa, e-mail: bernadete.sousa@ufjf.edu.br
}

SOUSA, B.M., GOMIDES, S.C., HUDSON, A.A., RIBEIRO, L.B. \& NOVELLI, I.A. Reptiles of the municipality of Juiz de Fora, Minas Gerais state, Brazil. Biota Neotrop. 12(3): http://www.biotaneotropica.org.br/v12n3/ en/abstract?inventory+bn00512032012

\begin{abstract}
The Atlantic Forest of the state of Minas Gerais, as well as the remnants of this domain in the rest of Brazil, suffers a marked reduction in size and anthropogenic alteration. This habitat degradation is directly reflected in the decrease of species richness within these natural environments. In this sense, the inventory of extant species is necessary to understand the species composition of regions under threat. Despite the great richness of existing reptile species in Minas Gerais, the level of knowledge about the fauna in this state is considered unsatisfactory and very fragmented. The aim of this study was to record the composition of the reptile fauna of the municipality of Juiz de Fora through the revision of specimens housed at the Herpetological Collection of the Federal University of Juiz de Fora (CHUFJF-Reptiles) and published papers. Better documentation of the reptilian fauna for the region not only expands the knowledge of the herpetofauna of Minas Gerais, but also contributes to regional conservation planning, such as "Biota Minas" program in the states of the Minas Gerais, Brazil. A total of 41 reptile species (two freshwater turtles, two amphisbaenians, 13 lizards and 24 snakes) belonging to 12 families were recorded. We highlight the record of the freshwater turtle Hydromedusa maximiliani, which is considered a species sensitive to anthropogenic impact and currently is seen only in protected areas in Juiz de Fora, as well as Ecpleopus gaudichaudii, Enyalius brasiliensis, Heterodactylus imbricatus, Placosoma glabellum and Micrurus corallinus, that are dependent on well-preserved forest areas. The reptile composition is more similar to Viçosa and other surrounding regions, despite the presence of many species that are not shared between these locations. This fact demonstrates the importance of the collection in terms of representativeness of the local and regional fauna as well as providing a valuable source of information for future studies of Brazilian herpetofauna in general.
\end{abstract}

Keywords: testudines, squamata, Atlantic Forest, zona da mata mineira, Minas Gerais.

SOUSA, B. M., GOMIDES, S. C., HUDSON, A. A., RIBEIRO, L. B. \& NOVELLI, I.A. Répteis do município de Juiz de Fora, Minas Gerais, Brasil. Biota Neotrop. 12(3): http://www.biotaneotropica.org.br/v12n3/pt/abs tract?inventory+bn00512032012

Resumo: A Mata Atlântica da Zona da Mata mineira, assim como os remanescentes deste domínio no restante do Brasil, sofre com a acentuada redução de área e antropização dos ambientes naturais. Essa degradação dos habitats reflete diretamente na riqueza de espécies que os compõe. Neste sentido, o inventário das espécies existentes torna-se necessário para conhecer e entender a composição de espécies ao longo deste bioma que é considerado um Hotspot de biodiversidade. Apesar da grande riqueza de espécies de répteis existentes em Minas Gerais, o nível de conhecimento sobre essa fauna no Estado é considerado insatisfatório e muito fragmentado. Nesta perspectiva, pretendeu-se com o presente estudo listar a composição da fauna de répteis do município de Juiz de Fora através de registros contidos na Coleção Herpetológica da Universidade Federal de Juiz de Fora (CHUFJF-Répteis) e de trabalhos publicados. Adicionalmente, propõe-se que a composição da fauna reptiliana documentada neste estudo, não apenas amplie o conhecimento sobre a herpetofauna de Minas Gerais, mas que também contribua para o planejamento futuro de projetos de conservação da biodiversidade do Estado, como o programa Biota Minas. Um total de 41 espécies de répteis (duas de cágados, duas de anfisbenas, 13 de lagartos e 24 de serpentes) pertencentes a 12 famílias foi registrado. Destaca-se o registro do cágado Hydromedusa maximiliani, que é considerado sensível aos processos de impacto antrópico e atualmente só é encontrado em áreas protegidas 
Sousa, B.M. et al.

do município, bem como as espécies Ecpleopus gaudichaudii, Enyalius brasiliensis, Heterodactylus imbricatus, Placosoma glabellum e Micrurus corallinus, que são dependentes de habitats florestais pouco impactados. A composição de répteis do município de Juiz de Fora é mais similar à da região de Viçosa e outras regiões circunvizinhas, apesar de apresentar muitas espécies que não são compartilhadas entre essas localidades, o que demonstra a importância da coleção em termos de representatividade da fauna local e regional, além de ser uma fonte inestimável de informações para estudos que abranjam a herpetofauna brasileira.

Palavras-chave: testudines, squamata, Mata Atlântica, zona da mata mineira, Minas Gerais.

\section{Introduction}

The Brazilian Atlantic Forest is considered one of the most important "hotspots" on the planet in terms of biodiversity, which means that it is a place with high concentration of endemic species, but one that is suffering an accelerated process of degradation and loss of habitat (Myers et al. 2000, Mittermeier et al. 2004). Most of the remaining Brazilian Atlantic Forest is in the form of small fragments, which are mostly embedded in arrays of pastures and urban areas and suffer from all kinds of anthropic intervention (Ribeiro et al. 2009b).

The main factor indicated for the $82 \%$ decline of threatened fauna in Minas Gerais is the loss of habitat, and approximately $60 \%$ of this fauna is associated with the Atlantic Forest (Antonini \& Drummond 2006). Analysis of satellite images has shown that the replacement of large areas of forests by farming, infrastructure and urban sprawl continues to occur at an accelerated pace (Antonini \& Drummond 2006). The Atlantic Forest originally covered $41 \%$ of the surface of the State area and now is restricted to only $4 \%$ of this area (Drummond et al. 2009). Although deforestation has fallen 58\% in Atlantic Forest area in 2011, about half of 13,300 hectares deforested in this domain is in the state of Minas Gerais state (Instituto... 2012). The Juiz de Fora municipality, which had 16\% of the remnants of Atlantic Forest area in 2010, presented a rate of $16 \%$ of deforestation between 2008 and 2010 (Fundação... 2011). The Atlantic Forest domain in Minas Gerais state had only 5 to $6 \%$ native forest in the 1980s according to Fonseca (1985). Currently, many typical forest species in this region are restricted to only a few conservation units or remnants (Bertoluci 1998) and much of the local biodiversity is unlikely to still exist in the region (e.g., Ribon et al. 2003) as a result of this high degree of devastation.

Although Minas Gerais harbors 32\% of the total richness of existing reptiles in Brazil (Bérnils et al. 2009), the level of knowledge about the reptilian fauna in the state is still unsatisfactory and very fragmented (Drummond et al. 2005). Studies that characterize the composition of reptiles in Minas Gerais are scarce, and there is little information on the biology and current state of conservation of this group (Brites \& Bauab 1988, Assis 1999, Feio \& Caramaschi 2002, Recoder \& Nogueira 2007, Bertoluci et al. 2009, Costa et al. 2009, 2010, Palmuti et al. 2009, São Pedro \& Pires 2009, Sousa et al. 2010). This lack of information on the reptile fauna of Minas Gerais consequently hinders the establishment of conservation areas that can preserve the herpetofauna (Drummond et al. 2005).

In this respect, our aim here is to record the composition of the reptile fauna of the municipality of Juiz de Fora using data from the Herpetological Collection of the Federal University of Juiz de Fora and published works, aiming to increase knowledge of the herpetofauna of Minas Gerais and to contribute to the planning and development of projects for biodiversity conservation in the state.

\section{Materials and Methods}

\section{Study area}

The study was conducted in the municipality of Juiz de Fora $\left(21^{\circ}\right.$ $41^{\prime} 20^{\prime}$ ' S and $43^{\circ} 20^{\prime} 40^{\prime \prime} \mathrm{W}$ ) in the Atlantic Forest zone of the state of Minas Gerais, southeastern Brazil, which is part of the Atlantic Forest morphoclimatic domain (Figure 1). The climate is Cwa type on the Köppen scale ("tropical de altitude") with two defined seasons: a hot and rainy summer (October to April) and a cooler and dryer winter (May to September). The average annual rainfall is $1,536 \mathrm{~mm}$ and average annual temperatures is $19.4{ }^{\circ} \mathrm{C}$. The hottest month is February, averaging close to $23.6^{\circ} \mathrm{C}$, and the coldest months are July and August, with an average of $15.8^{\circ} \mathrm{C}$ (Juiz de Fora 2004). Forest fragments in Juiz de Fora are classified as semi deciduous forest, and the matrix is composed primarily of urban areas and pastures, with elevation ranging from 467 to $1,104 \mathrm{~m}$ (Pifano et al. 2007).

\section{Data collection}

The data on the reptile fauna of Juiz de Fora in this study come from specimens deposited in the Herpetological Collection of Juiz de Fora Federal University (CHUFJF-Reptiles). These specimens were collected in urban and rural areas of the city between 2000 and 2011, mainly by university researchers, although some were delivered by the public or sent by public agencies. We also gathered secondary data from the literature. However, we have only included specimens for which we could confirm locality data.

Taxonomic and systematic discussions are continually changing the classification of some groups of herpetofauna, due to the use of modern techniques relying on molecular data to complement the traditional method of using morphological characters. This has generated a series of discussions and has clarified many questions about the taxonomy of various species (e.g., Di-Bernardo 1992, Wüster et al. 2002, Schargel et al. 2005, Curcio et al. 2009, Fenwick et al. 2009, Hoser 2009, Zaher et al. 2009, Vidal et al. 2010). To standardize the results, here we used the taxonomy recommended by the Brazilian Society of Herpetology (Bérnils \& Costa 2011), and some updates provided by Carrasco et al. (2012) and Ribeiro et al. (2011).

To compare the reptilian fauna of Juiz de Fora with other remnant Atlantic Forest areas in Minas Gerais, we used the works of Feio \& Caramaschi (2002), Palmuti et al. (2009), Costa et al. (2009, 2010) and Gomides \& Sousa (in press). We also included in the analysis work done in transitional areas between Cerrado (savanna) and Atlantic Forest domains, as reported by Bertoluci et al. (2009); São Pedro $\&$ Pires (2009) in a transition area with the occurrence of Campos Rupestres formation, and in a transition area in Campos das Vertentes region (Sousa et al. 2010). In addition, we included data from Recoder $\&$ Nogueira (2007) for a Cerrado area of the state (Table 2).

The reptilian fauna composition was analyzed and compared by applying the Jaccard similarity coefficient (Magurran 1988) and subsequent cluster analysis by the unweighted average method (UPGMA) (Krebs 1999). To evaluate the loss of information in the construction of dendrograms, we calculated the cophenetic correlation coefficient (r) (Romesburg 1984), obtained by correlating the original similarity matrix with the matrix obtained from the dendrogram, and the value of $r>0.9$ was considered a very good fit, $0.8<r<0.9$ was 


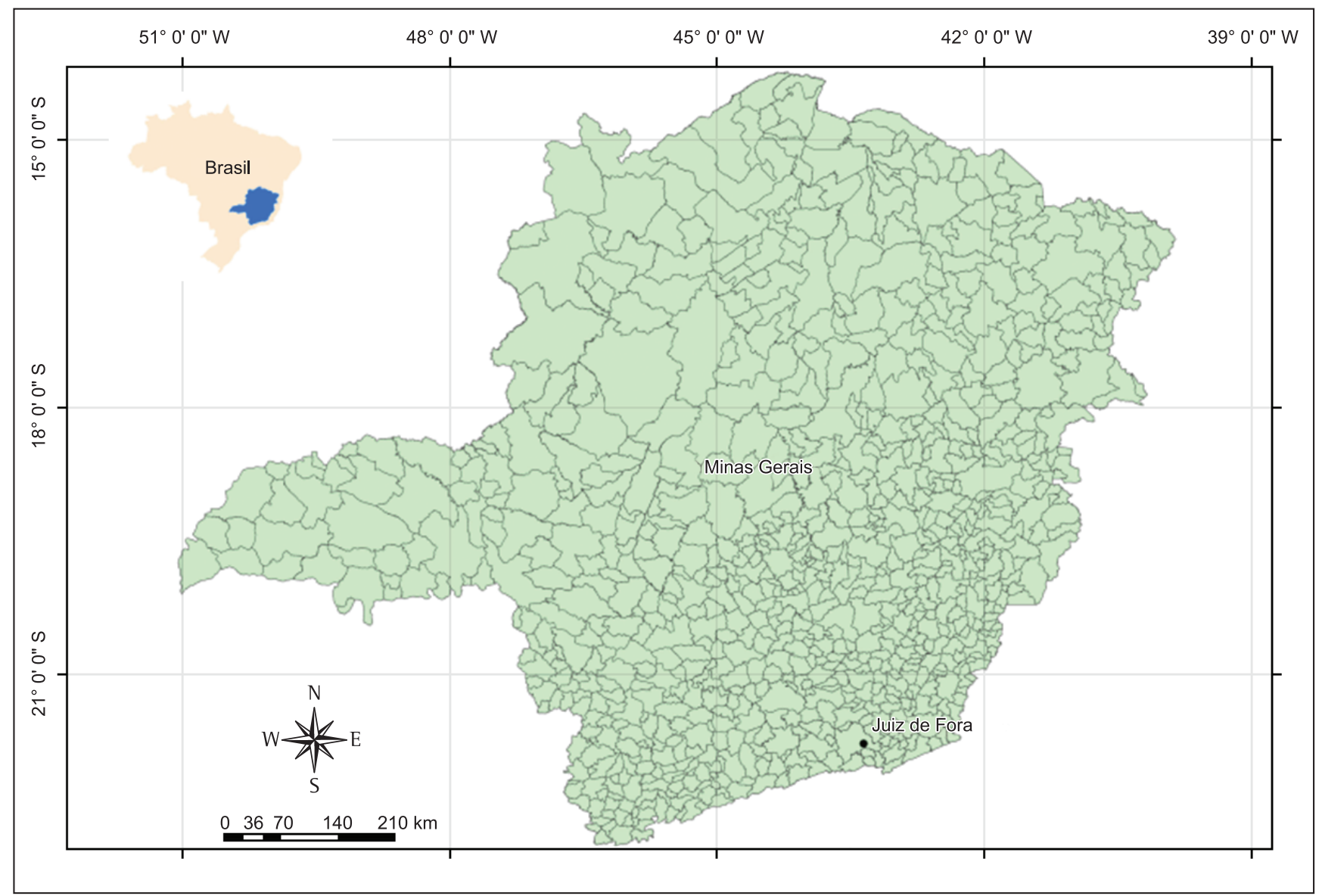

Figure 1. Location of the municipality of Juiz de Fora, Minas Gerais state, Brazil.

Figura 1. Localização do município de Juiz de Fora, Minas Gerais, Brasil.

considered a good fit, $0.7<\mathrm{r}<0.8$ was considered a poor fit and $\mathrm{r}<0.7$ was considered a very poor fit.

The data were compiled into a binary matrix representing the presence/absence of 123 species. To minimize taxonomic problems among the original lists, were removed from the matrix the species with uncertain identification (e.g., "gr." and "aff.") or without specific identification (e.g., "sp."), due to the impossibility of examining the all voucher specimens from other authors. The species cited as "cf." by other authors were kept. The species recorded through secondary means (such as photographs, were not counted).

\section{Results}

In total we recorded 41 species of reptiles (two freshwater turtles, two amphisbaenians, 13 lizards and 24 snakes) belonging to 12 families. Of these, 36 were deposited in the CHUFJF. Only one family of turtle was recorded (Chelidae), with two species, and only two species of Amphisbaenia. For the lizards, there were 13 species in seven families included. Finally, there were 24 species of snakes, belonging to three families (Table 1).

The similarity dendrogram (cophenetic correlation coefficient $=0.9088)($ Figure 2$)$ showed that the reptile fauna of Juiz de Fora is more similar to the region of Viçosa (Costa et al. 2009, 2010). These two locations have in common 30 species, and in contrast, 41 different species, which helps to confirm the high diversity between the regions of the state of Minas Gerais, which provides a high gamma diversity for the state as a whole. The other regions showed low similarity in species composition. Areas less similar in the present study, as one would expect, are the northern localities in the state, one of which is a typical Cerrado area.

\section{Discussion}

The number of reptile species recorded in this work represents $18.5 \%$ of the total estimate for the state of Minas Gerais according to Bérnils et al. (2009), and about $5.7 \%$ of the Brazilian reptile fauna (Bérnils \& Costa 2011). We recorded in Juiz de Fora, 17.2\% of the known snake fauna in Minas Gerais, and for lizards, $22.8 \%$ of the total richness in Minas Gerais (Bérnils et al. 2009). These numbers are relevant, since "Zona da Mata" region is in an advanced devastation situation and very few natural areas still exist to house the native fauna.

However, the list presented here is likely underestimated, since many species expected to occur in the region were not recorded, and we expect that, with additional sampling efforts directed mainly at cryptic species such as fossorial snakes and amphisbaenians, this list will increase. Another fact that must be taken into consideration is the time of operation of the CHUFJF-Reptile collection (active since 2000), making this collection much more recent than that of the João Moojen Zoology Museum (in operation since 1933) in Viçosa, for example. The latter is an important source of information on regional diversity, since the region is under represented in other Brazilian reference collections (Costa et al. 2010), such as the herpetological collections of the National Museum of Rio de Janeiro Federal University and the Zoology Museum of the University of São Paulo, which are the largest collections of reptiles in the Neotropical Region 
Sousa, B.M. et al.

Table 1. List of reptile species recorded in the municipality of Juiz de Fora, Minas Gerais, Brazil, between 2000 and 2011, with notes on habitat and distribution. Tabela 1. Lista das espécies de répteis registradas para o município de Juiz de Fora, Minas Gerais, Brasil, no período entre os anos de 2000 e 2011 , com notas sobre habitat e distribuição.

\begin{tabular}{cccc}
\hline Species & Habitat & Distribution & References \\
\hline TESTUDINES & &
\end{tabular}

\section{Chelidae}

Hydromedusa maximiliani

(Mikan, 1820)

Phrynops geoffroanus

(Schweigger, 1812)

SQUAMATA - AMPHISBAENIA

Amphisbaenidae

Amphisbaena cf. alba Linnaeus, 1758 Fossorial species in Atlantic South America as fare south as Vanzolini 2002

Leposternon microcephalum

(Wagler, 1824)

SQUAMATA - LIZARDS

\section{Leiosauridae}

Enyalius bilineatus Duméril \& Impacted and altered areas Bibron, 1837

Enyalius brasiliensis (Lesson, 1828) Dense Atlantic Forest areas

Enyalius perditus Jackson, 1978

Urostrophus vautieri

Duméril \& Bibron, 1837

\section{Tropiduridae}

Tropidurus torquatus (Wied, 1820)

\section{Gekkonidae}

Hemidactylus mabouia

(Moreau de Jonnès, 1818)

\section{Anguidae}

Ophiodes striatus (Spix, 1825)

\section{Teiidae}

Tupinambis merianae

(Duméril \& Bibron, 1839)

\section{Gymnophthalmidae}

Ecpleopus gaudichaudii

Duméril \& Bibron, 1839
Forest areas, Cerrado and Paraguay

Caatinga regions

Streams and water bodies Minas Gerais, São Paulo, Rio Ernst \& Barbour (1989), Argôlo associated with regions of de Janeiro, Espírito Santo and \& Freitas (2002), Souza et al. mountains of the Atlantic Forest southern Bahia

(2003), Souza (2004), Novelli \& Sousa (2007)

Lakes, ponds, streams and rivers Colombian Amazon to the state Ernst \& Barbour (1989), Lema and disturbed environments, of Rio Grande do Sul, and also \& Ferreira (1990), McCord et al. such as reservoirs parts of Uruguay and northern (2001), Souza \& Abe (2001) Argentina

Fossorial species in Atlantic Wide distribution in Brazil and Perez \& Ribeiro (2008), Costa et al. Forest areas, Cerrado and also occurs in Bolivia, Paraguay, (2009), Sousa et al. (2010) Caatinga regions Argentina and Uruguay or forest borders in the Atlantic Forest, areas of coffee plantations and Cerrado
Central and Southeastern Brazil Jackson (1978), Nogueira (2001), Zatz (2002), Teixeira et al. (2005), Sousa et al. (2010)

Minas Gerais, Rio de Janeiro Jackson (1978), Van Sluys et al. and Espírito Santo (2004), Teixeira et al. (2005), Costa et al. 2009, Gomides et al. (2010)

Atlantic Forest and urban forest Rio de Janeiro, São Paulo and Jackson (1978), Sousa \& Cruz fragments Minas Gerais (2008), Dixo \& Metzger (2009), Gomides et al. (2010)

Forested areas like the Cerrado Minas Gerais, Espírito Santo, Etheridge \& Williams (1991), and semideciduous forest Rio de Janeiro, São Paulo and Marques et al. (1998), Santos et al. southern Brazil
Open areas, such as rock Midwest, Northeast (south of Araújo (1987), Rodrigues (1987), outcrops and in environments Bahia), Southeast and South Rocha (2000), Ribeiro et al. altered by human action, regions of Brazil occurring abundantly even in urban areas

Disturbed and natural areas Colonized all of the Americas Carranza \& Arnold (2006)

Campos de Altitude formation Southeastern and central Brazil Martins (1998) in the Atlantic Forest, Cerrado areas and Araucaria Forest

All types of environments from Northern Argentina, Uruguay, a Vanzolini et al. (1980), Ávila Pires human-altered (deforested large portion of Brazil's Amazon (1995), Marques \& Sazima (2004) areas) to forest borders and in southern Atlantic Forest regions

Leaf litter of forests in the Southern and southeastern Uzzell Junior (1969), Dixo \& Atlantic Forest Brazil Metzger (2009) 
Table 1. Continued...

\begin{tabular}{|c|c|c|c|}
\hline Species & Habitat & Distribution & References \\
\hline $\begin{array}{l}\text { Heterodactylus imbricatus } \\
\text { Spix, } 1825\end{array}$ & $\begin{array}{l}\text { Cryptozoic habits in forest litter } \\
\text { at high altitudes of the Atlantic } \\
\text { Forest and in areas of Cerrado } \\
\text { gallery forest }\end{array}$ & $\begin{array}{l}\text { Southeastern Brazil (Minas } \\
\text { Gerais, Rio de Janeiro, São } \\
\text { Paulo, Espírito Santo) }\end{array}$ & $\begin{array}{l}\text { Dixo \& Metzger (2009), } \\
\text { Novelli et al. (2011) }\end{array}$ \\
\hline Placosoma glabellum (Peters, 1870) & $\begin{array}{l}\text { Inhabits forest litter in the } \\
\text { Atlantic Forest }\end{array}$ & $\begin{array}{l}\text { Southern and southeastern } \\
\text { Brazil }\end{array}$ & $\begin{array}{l}\text { Uzzell Junior (1959), Condez et al. } \\
\text { (2009), Forlani et al. (2010) }\end{array}$ \\
\hline
\end{tabular}

\section{Scincidae}

Mabuya dorsivittata Cope, 1862

Mabuya frenata (Cope, 1862)

SQUAMATA - SNAKES

\section{Colubridae}

Chironius bicarinatus (Wied, 1820) Areas of rainforest along the Bahia to Rio Grande do Sul, Dixon et al. (1993), Cicchi et al. coast, tropical seasonal forest and can be found in Argentina (2007), Costa et al. (2010), in the hinterland and riparian and Uruguay forests of the Cerrado Forlani et al. (2010), Nogueira et al. (2011)

Chironius exoletus (Linnaeus, 1758) Forested areas, with records in Southern portion of Central Dixon et al. (1993), Morato(1995), the Amazon, Atlantic Forest, America to the Atlantic region Argôlo (2004), Kawashita-Ribeiro Pantanal and Cerrado. It can also of the southern state of Santa (2007), França et al. (2008) be found in open areas Catarina and the province of Misiones in Argentina

Elapomorphus quinquelineatus (Raddi, 1820)

Erythrolamprus aesculapii (Linnaeus, 1766)

Liophis miliaris (Linnaeus, 1758)

Fossorial species that is commonly found in forested and altered environments Brazil

Forested areas and in open areas Occurs from the Amazon to Marques (1996), Curcio (2008) the southernmost part of Brazil and is very common in the southeastern Atlantic Forest

Forested areas and in open Occurs from the Amazon basin Dixon (1989), Argôlo (2004), formations in the Amazon, to states of Rio Grande do Norte Marques \& Sazima (2004)

Atlantic Forest, Caatinga and to Rio Grande do Sul

Cerrado

Liophis poecilogyrus (Wied, 1825) Inhabits forests and Distribution throughout South Pontes \& Rocha (2008) anthropogenic areas America, from the Amazon basin to Argentina

Liophis typhlus (Linnaeus, 1758)

Inhabits the Atlantic Forest, Widely distributed in Brazil Cerrado and Caatinga, even in Marques et al. (2009), Sousa et al. anthropic environments

Oxyrhopus clathratus Duméril, Inhabits forests and anthropic Distributed from northeastern Peters \& Orejas-Miranda (1986), Bibron \& Duméril, $1854 \quad$ environments

Oxyrhopus guibei

Hoge \& Romano, (1978)

Philodryas olfersii

(Lichtenstein, 1823)

Philodryas patagoniensis (Girard, 1858) to southern Brazil, from Bahia Argôlo (2001), Morato (2005), to Rio Grande do Sul, also Marques et al. (2009) occurring in Misiones, Argentina

Very common in open areas Occurs from the Northeast, Hoge \& Romano (1976), Andrade and forest borders, as well as Midwest and South regions \& Silvano (1996), Freire (1999), the Cerrado of Brazil as well as Bolivia, Sawaya et al. (2008), Forlani et al. Paraguay, Uruguay and northern (2010) and northeastern Argentina

Forested areas and in open areas Distributed from southern Thomas (1976), Argôlo (2004), Argentina, Paraguay, Uruguay Hartmann \& Marques (2005), and Bolivia to central Brazil Pontes \& Rocha (2008)

Occurs mainly in open areas, Argentina, Chile, Uruguay, Hartmann \& Marques (2005), forest borders and areas of Paraguay, Bolivia. In Brazil Sawaya et al. (2008), Costa et al. Cerrado and Atlantic Forest of it occurs from Rio Grande do (2010), Uetz \& Hallermann (2011) Brazil 
Table 1. Continued...

\begin{tabular}{|c|c|c|c|}
\hline Species & Habitat & Distribution & References \\
\hline $\begin{array}{l}\text { Sibynomorphus mikanii } \\
\text { (Schlegel, 1837) }\end{array}$ & $\begin{array}{l}\text { Atlantic Forest regions, as } \\
\text { well as in areas of Cerrado } \\
\text { and semideciduous forest and } \\
\text { disturbed areas }\end{array}$ & $\begin{array}{l}\text { Distributed from the North and } \\
\text { Northeast regions of Brazil to } \\
\text { Argentina }\end{array}$ & $\begin{array}{l}\text { Franco (1994), Albuquerque \& } \\
\text { Ferrarezzi (2004), Sawaya et al } \\
\text { (2008), Forlani et al. (2010), }\end{array}$ \\
\hline $\begin{array}{l}\text { Sibynomorphus neuwiedi } \\
\text { (Ihering, 1911) }\end{array}$ & $\begin{array}{l}\text { Atlantic Forest areas, as well as } \\
\text { in altered environments }\end{array}$ & $\begin{array}{l}\text { Occurs from Bahia to Rio } \\
\text { Grande do Sul }\end{array}$ & $\begin{array}{l}\text { Marques \& Sazima (2004), Moratc } \\
\text { (2005), Forlani et al. (2010) }\end{array}$ \\
\hline Spilotes pullatus (Linnaeus, 1758) & $\begin{array}{l}\text { Forested environments and in } \\
\text { open and changed fields }\end{array}$ & $\begin{array}{l}\text { Central and South America, } \\
\text { from Costa Rica to Argentina }\end{array}$ & $\begin{array}{l}\text { Cunha \& Nascimento (1978) } \\
\text { Argôlo (2004), Forlani et al. (2010) }\end{array}$ \\
\hline
\end{tabular}

Taeniophallus affinis (Günther, 1858) Endemic to Atlantic coastal Distributed from the Northeast Di-Bernardo (1992), Freire \& Silva areas, occurring in forested and to the South of Brazil (2000), Loebmann (2008) open areas

Thamnodynastes cf. nattereri (Mikan, 1828)

Tropidodryas striaticeps

(Cope, 1869)

Xenodon merremii (Wagler, 1824)

Xenodon neuwiedii Günther, 1863

\section{Elapidae}

Micrurus corallinus (Merrem, 1820)

\section{Viperidae}

Bothrops alternatus

(Duméril, Bibron \& Duméril, 1854)

Found in swamps and marshes Occurs to southern and central Lema (1987), Mesquita \& Brites as sugarcane fields and coffee Grosso, Minas Gerais, São São Pedro \& Pires (2009) groves

Paulo, Parana, Santa Catarina,

Rio Grande do Sul), Paraguay,

Uruguay and Argentina

Bothrops jararaca (Wied, 1824)

Bothrops neuwiedi (Wagler, 1824)

Common in areas of Atlantic Distributed from the states of Sazima \& Haddad (1992), Martins Forest, occurring both in open Bahia to Rio Grande do Sul, et al. (2001), Campbell \& Lamar areas and in forested areas, as also occurring in Argentina and (2004), Condez et al. (2009), well as in forest borders and Paraguay disturbed areas

Forlani et al. (2010)

Typical species of the Cerrado In occurs in Brazil only in the Silva \& Rodrigues (2008), and also occurs in areas of states of Bahia, Goiás, Minas São Pedro \& Pires (2009), transition between Cerrado and Gerais, Rio de Janeiro, São Sousa et al. (2010)

Atlantic Forest

Paulo, Santa Catarina and possibly in northern Rio Grande do Sul

Crotalus durissus (Linnaeus, 1758) Occurrs naturally in open Widespread distribution Sazima \& Haddad (1992), formations, and adapts well to throughout South America Marques et al. (2001), Bastos et deforested areas except Ecuador and Chile al. (2005), Campbell \& Lamar (2004), Wüster et al. (2005)
(South America and Central America). These facts demonstrate the importance of regional collections, and highlight how the reptilian fauna of the CHUFJF-Reptiles can be representative of local, regional and even national levels.

The area whose species composition is most similar to that of Juiz de Fora is the municipality of Viçosa and its surrounding area.
This result is expected given the similarity between the vegetation cover and geographical proximity between the two municipalities (approximately $120 \mathrm{~km}$ ). Nevertheless, there is a high rate of species substitution between these two cities, emphasizing the heterogeneity of species composition of "Zona da Mata" region and highlighting Minas Gerais biodiversity. However, other areas such as the transition 
Table 2. Papers used to compare the list of reptile species in the municipality of Juiz de Fora, Minas Gerais, Brazil, with other locations in Minas Gerais. Tabela 2. Trabalhos de outras localidades do estado de Minas Gerais utilizados para comparação com a lista de espécies de répteis do município de Juiz de Fora, Minas Gerais, Brasil.

\begin{tabular}{|c|c|c|c|}
\hline Place/city & Biome & $\begin{array}{c}\text { Number of } \\
\text { species recorded }\end{array}$ & References \\
\hline $\begin{array}{l}\text { Various forest fragments in the Jequitinhonha river } \\
\text { basin, in northeastern part of the state }\end{array}$ & Atlantic Forest & 11 & Feio \& Caramaschi (2002) \\
\hline RPPN Feliciano Miguel Abdala/Caratinga & Atlantic Forest & 20 (only snakes) & Palmuti et al. (2009) \\
\hline Viçosa and surrounding region & Atlantic Forest & 53 & Costa et al. $(2009,2010)$ \\
\hline RPPN Alto da Boa Vista/Descoberto & Atlantic Forest & 16 & Gomides \& Sousa (in press) \\
\hline $\begin{array}{l}\text { Peti Environmental Station/São Gonçalo do Rio } \\
\text { Abaixo e Santa Bárbara }\end{array}$ & Atlantic Forest and Cerrado & 18 & Bertoluci et al. (2009) \\
\hline Ouro Branco and surrounding region & $\begin{array}{l}\text { Atlantic Forest, Cerrado } \\
\text { and Campo Rupestre }\end{array}$ & 28 (only snakes) & São Pedro \& Pires (2009) \\
\hline Ritápolis and surrounding region & Atlantic Forest and Cerrado & 31 & Sousa et al. (2010) \\
\hline $\begin{array}{l}\text { Parque Nacional Grande Sertão Veredas, border area } \\
\text { between the states of Minas Gerais and Bahia }\end{array}$ & Cerrado & 50 & Recoder \& Nogueira (2007) \\
\hline Juiz de Fora & Atlantic Forest & 41 & This study \\
\hline
\end{tabular}

between the Cerrado and Atlantic Forest also have some similarity because of the occurrence of widespread species shared between the two regions. The information about the geographical distribution and biology of the reptile species recorded for Juiz de Fora in the Herpetological Collection of Juiz de Fora Federal University (CHUFJF-Reptiles) is listed in Tables 1 and 2. Relevant information of the local fauna is summarized and presented below.

\section{TESTUDINES}

Hydromedusa maximiliani (Figure 3a) is classified as Near Threatened by the Brazilian Institute of Environment and Renewable Natural Resources (IBAMA) (Rodrigues 2005) and as vulnerable by the IUCN (International... 2011). In Juiz de Fora it is found in streams and backwaters of some protected and well-preserved forested areas, and so far has not been found in open or disturbed areas, highlighting the importance of conservation of remnant vegetation in the municipality. Phrynops geoffroanus (Figure 3b) is found in Juiz de Fora in natural and disturbed environments, such as reservoirs, and also in the Paraibuna River, which crosses the city and is highly polluted.

\section{SQUAMATA - AMPHISBAENIA}

Amphisbaena cf. alba has been recorded for the city, but has no representative in CHUFJ-Reptiles, with records for the municipality of Viçosa (Costa et al. 2009). Amphisbaenids, being fossorial species, are usually recorded opportunistically. In this case, we have only one specimen photographed. Leposternon microcephalum is the most common amphisbaenid found in the municipality of Juiz de Fora. In Minas Gerais, it was also reported by Costa et al. (2009) for the Atlantic Forest area of Viçosa.

\section{SQUAMATA - LIZARDS}

The species Enyalius bilineatus was recorded in preserved areas of the Peti Environmental Station in Minas Gerais state (Bertoluci et al 2009). There are additional records for areas of disturbed and regenerating forest in Viçosa (Costa et al. 2009). In Juiz de Fora, E. bilineatus is found mainly in forest borders and urban forest fragments (Gomides et al. 2010). Enyalius brasiliensis (Figure 3c) is a rare species in Juiz de Fora, found only in a particular property of forest fragment well preserved of 370 hectares (Gomides et al. 2010). Enyalius perditus (Figure 3d) is the most abundant lizard species in urban forest fragments in Juiz de Fora (Sousa, personal observation), occurring only in small forest fragments ( 80 to 400 ha) which have suffered human impacts (portions of grazing areas in regeneration).
In São Paulo, the species is sensitive to forest fragmentation but seems to tolerate disturbed environments (Dixo \& Metzger 2009). Urostrophus vautieri (Figure 3e) is a lizard that in Juiz de Fora can be found on the university campus (Ribeiro \& Sousa 2006) and in other fragments of Atlantic Forest.

Tropidurus torquatus (Figure $3 \mathrm{f}$ ) is the most abundant lizard species in open areas, often found in rocky outcrops in rural areas and Hemidactylus mabouia, is also a species very common in Juiz de Fora. However, there are no records of this species in natural areas, only in the urban area.

Ophiodes striatus (Figure $3 \mathrm{~g}$ ) is a limbless lizard very common that occurs in Juiz de Fora, both in disturbed areas and preserved ones, such as the campus of Juiz de Fora Federal University. As indicated by Martins (1998), a taxonomic revision was necessary for the genus, but despite this statement, the corresponding data for revision were not published

Tupinambis merianae (Figure $3 \mathrm{~h}$ ) is a large sized species of lizard very common in Juiz de Fora, that is listed as vulnerable in Appendix II of CITES because it is targeted by hunters because mainly of their skin value (Mieres \& Fitzgerald 2006). This happens in the Atlantic Forest zone of the state of Minas Gerais, where it is used also as food in rural areas (Sousa, personal observation).

Ecpleopus gaudichaudii (Figure 3i) is a small gymnophthalmid lizard that has a wide distribution in the Atlantic Forest. It is relatively common species although not easily seen because of its cryptozoic habits and small size (Condez et al. 2009). Several specimens were captured in pitfall and funnel traps installed in forest fragments in Juiz de Fora. Heterodactylus imbricatus is also gymnophthalmid lizard with cryptozoic habits, living in forest litter. It can be considered rare in the forest habitats sampled in Juiz de Fora, as only one specimen from Juiz de Fora has been housed in CHUFJF. Placosoma glabellum (Figure $3 \mathrm{j}$ ) is a small gymnophthalmid lizard that is very common in Juiz de Fora and is frequently captured in funnel traps installed in forest fragments. However, a specimen was found in a bush a few centimeters from the ground. Contrary to the sympatric microteiides, this species is more scansorial and commonly found on vegetation (Marques \& Sazima 2004).

Mabuya dorsivittata (Figure 3k) and Mabuya frenata are scincid lizards that have wide distribution in open areas, both species are uncommon in the samples and the collection.

SQUAMATA - SNAKES 


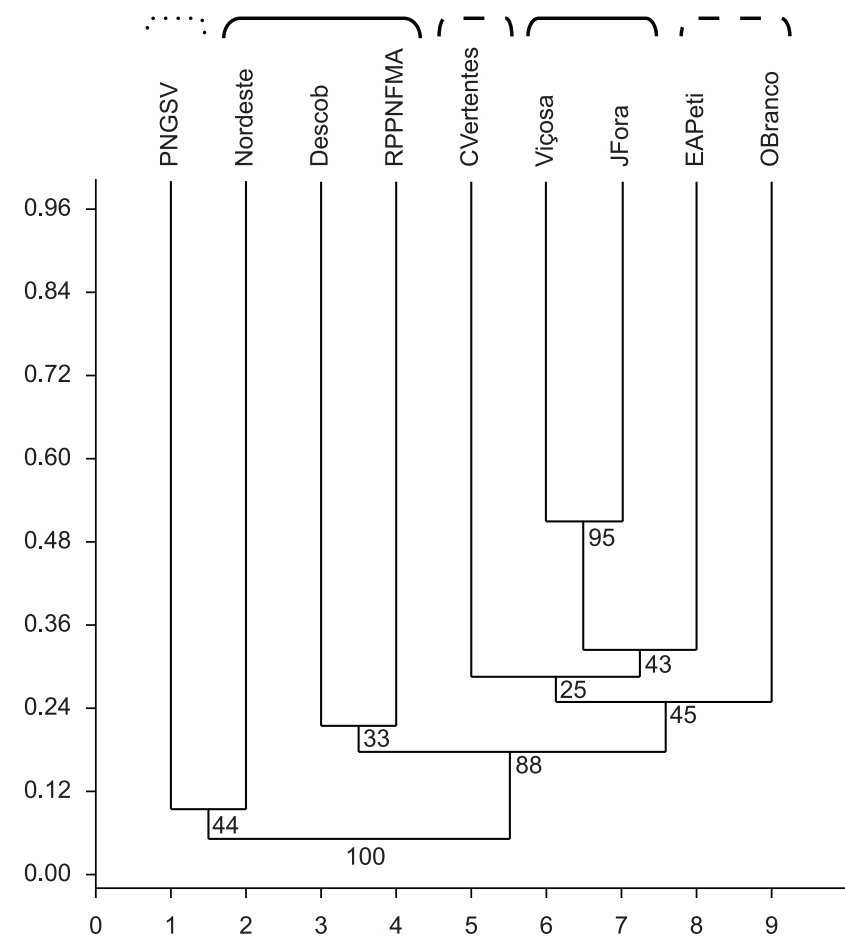

Figure 2. Similarity dendrogram of the composition of reptile species in the municipality of Juiz de Fora and other regions of the Atlantic Forest and Atlantic Forest/Cerrado transitional areas in Minas Gerais state. Jaccard index and UPGMA clustering method (cophenetic correlation coefficient $=0.9088$ ). The dotted line refers to the Cerrado area, the solid line refers to Atlantic Forest area and the dashed line refers to areas of transition between biomes. PNGSV = Parque Nacional Grande Sertões Veredas, Nordeste $=$ northeastern region of Minas Gerais; Descob $=$ RPPNAlto da Boa Vista, Descoberto; RPPNFMA = RPPN Feliciano Miguel Abdala, Caratinga; CVertentes $=$ Ritápolis region, Campo das Vertentes region; Viçosa $=$ Viçosa region; JFora $=$ Juiz de Fora; EAPeti $=$ Peti Environmental Station, between the municipalities of São Gonçalo do Rio Abaixo and Santa Bárbara; OBranco $=$ Ouro Branco region.

Figura 2. Dendrograma de similaridade das listas de composição das espécies de répteis entre a cidade de Juiz de Fora e outras regiões de Mata Atlântica e áreas de transição Mata Atlântica/Cerrado no estado de Minas Gerais. Índice de Jaccard e método de agrupamento "UPGMA" (Coeficiente de Correlação Cofenética $=0,9088)$. A linha pontilhada se refere à área de Cerrado, a linha inteira a área de Mata Atlântica, e a linha tracejada se refere a áreas de transição entre os biomas. PNGSV = Parque Nacional Grande Sertão Veredas; Nordeste $=$ região nordeste do estado de Minas Gerais; Descob $=$ RPPN Alto da Boa Vista, Descoberto; RPPNFMA = RPPN Feliciano Miguel Abdala, Caratinga; CVertentes $=$ Ritápolis e região, região do Campo das Vertentes; Viçosa = Viçosa e região; JFora = Juiz de Fora; EAPeti = Estação Ambiental de Peti, entre as cidades de São Gonçalo do Rio Abaixo e Santa Bárbara; OBranco $=$ Ouro Branco e região.

The collection has only one specimen of Chironius bicarinatus and the occurrence of Chironius exoletus was recorded by CETAS/ JF (public agency for the purpose to receive, triage and manage the wild animals rescued or apprehended).

Elapomorphus quinquelineatus (Figure 4a) is a fossorial species that is commonly found in forested and altered environments of Juiz de Fora, with several specimens having been found on the campus of Juiz de Fora Federal University.

Erythrolamprus aesculapii (Figure 4b) is a false coral that has wide distribution in the Neotropical region and it is a rare species in Juiz de Fora, found only one specimen in a forest fragment. Oxyrhopus clathratus (Figure 4f) is an endemic species of the Atlantic
Forest (Sazima 2001). It inhabits forests and anthropic environments (Morato 2005, Marques et al. 2009), and its occurrence in forested or developed areas in Juiz de Fora is very common. Oxyrhopus guibei (Figure 4g) is very common in open areas and forest borders (Andrade \& Silvano 1996) and it often occurs in urban areas. Because of their coloring, these snakes are readily killed by people, who confuse them with the true coral snakes of the genus Micrurus.

Liophis miliaris (Figure 4c), Liophis poecilogyrus (Figure 4d) and Liophis typhlus (Figure 4e) are species widely distributed. Liophis miliaris can even be found near the seashore, foraging in mangroves and along rocky shores (Marques \& Souza 1993). It has a complex taxonomic history, with populations from different regions that may represent distinct species, requiring taxonomic revision (Costa et al. 2010). Liophis poecilogyrus has wide distribution, inhabiting forests and anthropogenic areas (Pontes \& Rocha 2008). This species needs taxonomic revision to clarify the relationship of the four subspecies (Forlani et al. 2010). Liophis typhlus is a species widely distributed in Brazil in the Atlantic Forest (Marques et al. 2009) and Cerrado (Sousa et al. 2010), even in anthropic environments. In Juiz de Fora, the three Liophis species are commonly found along the banks of water bodies, being L. miliaris the most common and L. typhus the rarest.

Philodryas olfersii (Figure 4h) has widespread distribution throughout South America and possibly represents a complex with more than one cryptic species (Thomas 1976, Forlani et al. 2010). It is considered as potentially causing bites, but since it has opisthoglyphous dentition, poisoning from this species are uncommon (Puorto \& França 2003). Philodryas patagoniensis (Figure 4i) in Minas Gerais, has been reported by São Pedro \& Pires (2009) in the city of Ouro Branco and by Costa et al. (2010) in a transition area between the Cerrado and Atlantic Forest in Viçosa (Atlantic Forest area).

Sibynomorphus mikanii (Figure 4j) is common even in urban environments, occurring in places like vacant lots (Brites \& Bauab 1988, Barbo 2008, Marques et al. 2009,). Sibynomorphus neuwiedi (Figure 4k) is quite common in southeastern Atlantic Forest areas (Marques et al. 2001). Sibynomorphus neuwiedi is common on the campus of Juiz de Fora Federal University and surrounding neighborhoods and we have only one record of the Sibynomorphus mikanii in the collection.

Spilotes pullatus (Figure 31) has wide distribution, occurring in forested environments and in open and secondary open areas, to which it appears to be very tolerant (Cunha \& Nascimento 1978, Argôlo 2004, Forlani et al. 2010). The various specimens reported in Juiz de Fora were found in forest fragments.

Taeniophallus affinis (Figure 41), being a cryptozoic snake (Sazima \& Haddad 1992, Marques et al. 2001, Pontes \& Rocha 2008), is difficultly sighted in field samples, although its occurrence in the forests of Juiz de Fora is common, but not very common in the collection.

Thamnodynastes cf. nattereri (treated as Thamnodynastes sp. in Franco \& Ferreira 2002) (Figure 5a) in Minas Gerais is found in transition areas between Cerrado and Atlantic Forest (Bertoluci et al. 2009, Costa et al. 2010), but with only one record in a forest fragment of Juiz de Fora. Tropidodryas striaticeps (Figure 5b) is a semiarboreal species, apparently diurnal snake, in Atlantic coastal regions, ecotonal regions of Atlantic Forest. It is a rare species in Juiz de Fora, with a single record from a well preserved 370 hectares privately owned forest fragment.

Xenodon merremii (Figure 5c) is widely distributed, being commonly found in open areas in Juiz de Fora and Xenodon neuwiedii is a species with wide geographical distribution, which mainly 

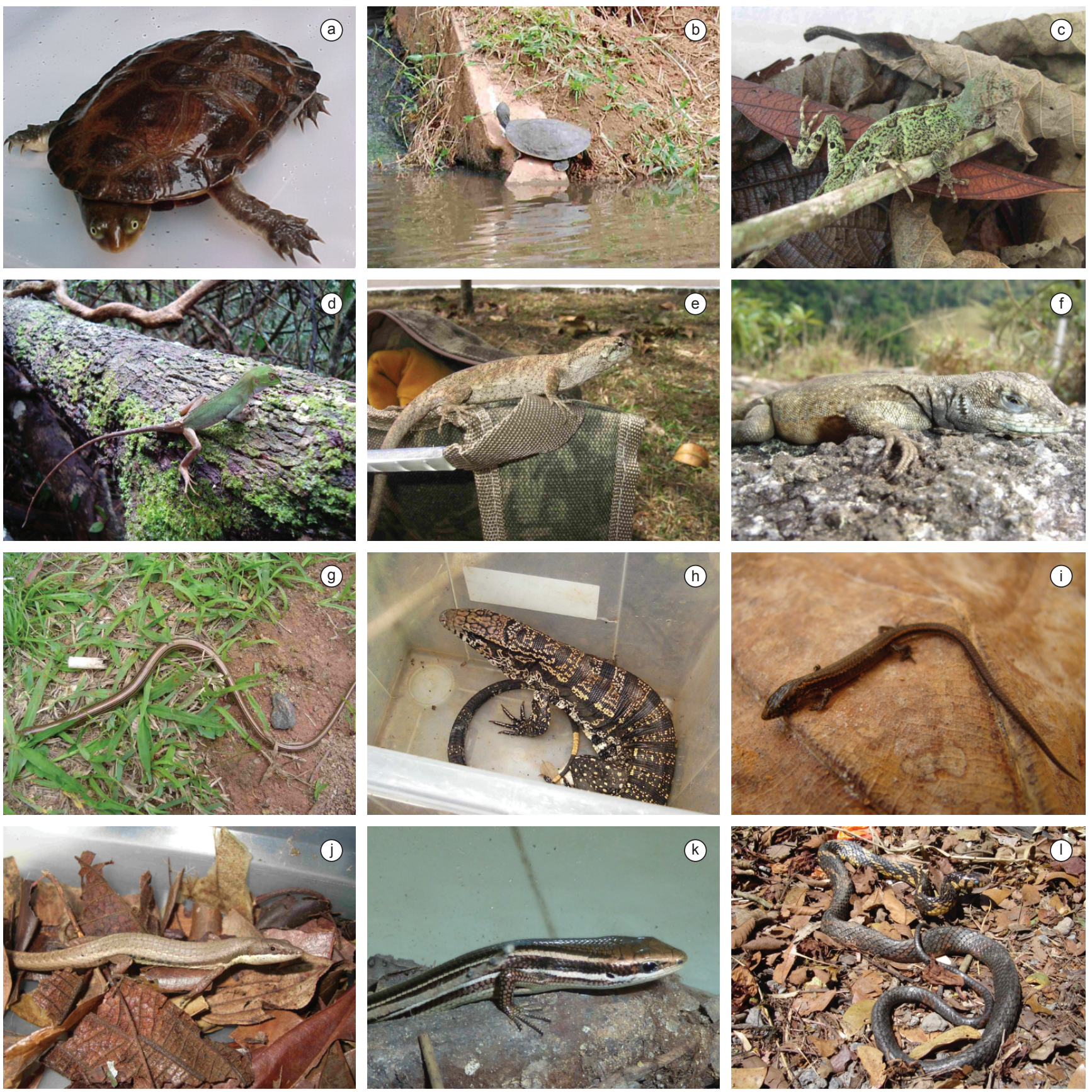

Figure 3. Some species of reptiles recorded in the municipality of Juiz de Fora, Minas Gerais, southeastern Brazil. a) Hydromedusa maximiliani; b) Phrynops geoffroanus (Fonte:Marcelo Ribeiro); c) Enyalius brasiliensis; d) Enyalius perditus; e) Urostrophus vautieri; f) Tropidurus torquatus; g) Ophiodes striatus; h) Tupinambis merianae; i) Ecpleopus gaudichaudii; j) Placosoma glabellum; k) Mabuya dorsivittata; and 1) Spilotes pullatus.

Figura 3. Algumas espécies de répteis registradas no município de Juiz de Fora, Minas Gerais, sudeste do Brasil. a) Hydromedusa maximiliani; b) Phrynops geoffroanus (Fonte:Marcelo Ribeiro); c) Enyalius brasiliensis; d) Enyalius perditus; e) Urostrophus vautieri; f) Tropidurus torquatus; g) Ophiodes striatus; h) Tupinambis merianae; i) Ecpleopus gaudichaudii; j) Placosoma glabellum; k) Mabuya dorsivittata; e 1) Spilotes pullatus.

inhabits forested. In Juiz de Fora both species are not very common in the collection.

Micrurus corallinus (Figure 5d) is a coral snake that occurs throughout the Atlantic Forest domain (Campbell \& Lamar 2004). The only specimen in the CHUFJF-Reptiles Collection was captured in the Lajinha Municipal Park, an urban forest fragment of Juiz de Fora.

Several specimens of Bothrops jararaca (Figure 5e) were captured in the research developed in the municipality of Juiz de Fora on urban forest fragment. It can cause serious accidents due to its abundance and aggressive behavior (Campbell \& Lamar 2004). Only one specimen photographed of Bothrops alternatus (Figure 5h) and only one specimen of the Bothrops neuwiedi (Figure 5f) is deposited in the collection.

Crotalus durissus (Figure $5 \mathrm{~g}$ ) is present in cleared rainforest areas due to deforestation (Marques et al. 2001). In Juiz de Fora, in recent years there has been a large increase in reports of $C$. durissus, causing a reversal in relation to reports of B. jararaca, according to data obtained from CETAS/JF. 

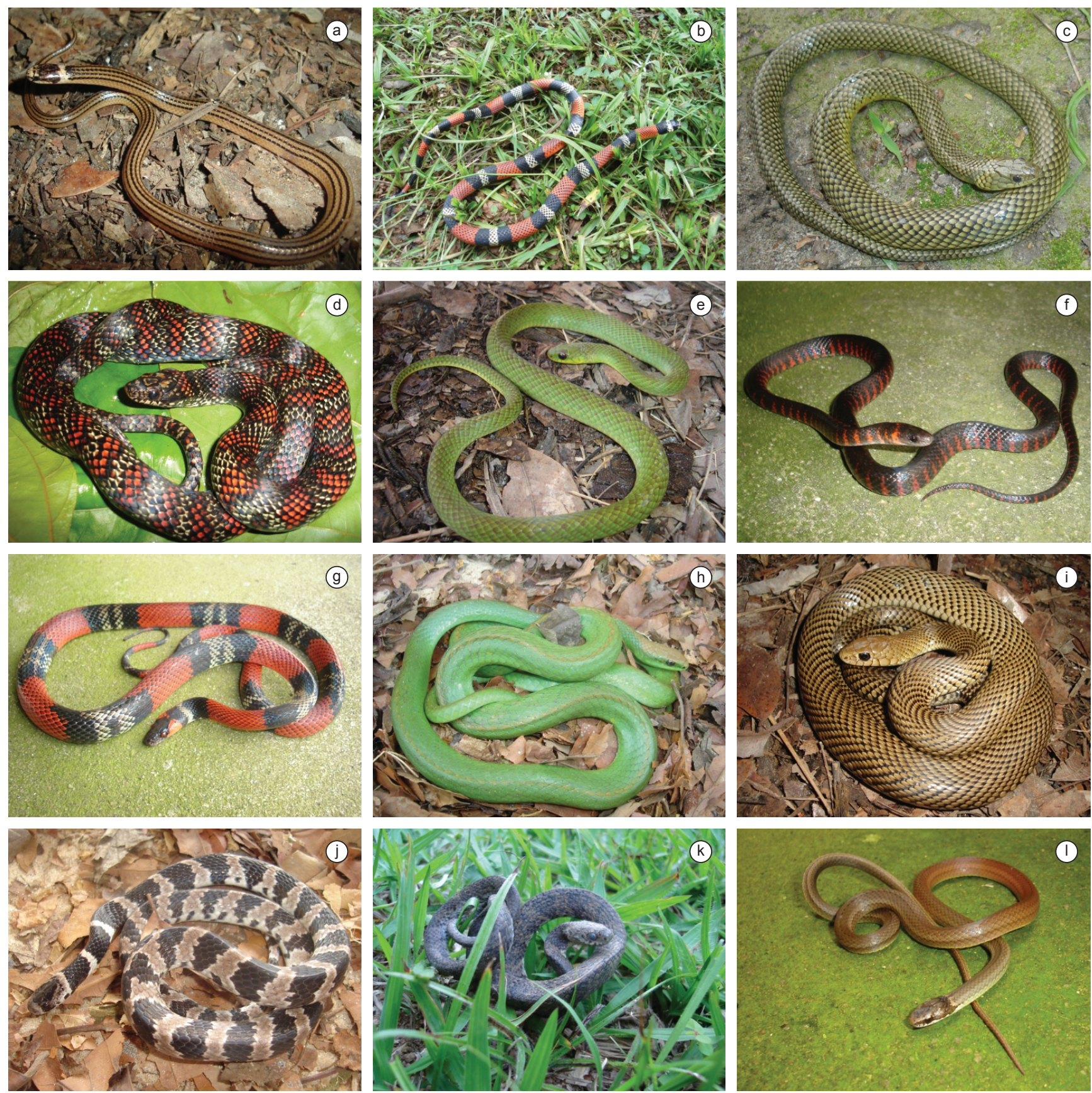

Figure 4. Some species of reptiles recorded in the municipality of Juiz de Fora, Minas Gerais, southeastern Brazil. a) Elapomorphus quinquelineatus; b) Erythrolamprus aesculapii; c) Liophis miliaris; d) Liophis poecilogyrus; e) Liophis typhlus; f) Oxyrhopus clathratus; g) Oxyrhopus guibei; h) Philodryas olfersii; i) Philodryas patagoniensis; j) Sibynomorphus mikanii; k) Sibynomorphus neuwiedi; and 1) Taeniophallus affinis.

Figura 4. Algumas espécies de répteis registradas no município de Juiz de Fora, Minas Gerais, sudeste do Brasil. a) Elapomorphus quinquelineatus; b) Erythrolamprus aesculapii; c) Liophis miliaris; d) Liophis poecilogyrus; e) Liophis typhlus; f) Oxyrhopus clathratus; g) Oxyrhopus guibei; h) Philodryas olfersii; i) Philodryas patagoniensis; j) Sibynomorphus mikanii; k) Sibynomorphus neuwiedi; e 1) Taeniophallus affinis.

The composition of the reptile fauna of the municipality of Juiz de Fora, Minas Gerais, showed that many species recorded are typical of open areas (e.g., Tropidurus torquatus, Mabuya dorsivittata, Crotalus durissus and Oxyrhopus guibei). Nevertheless, species that depend on well-preserved forest areas are still present (e.g., Hydromedusa maximiliani, Ecpleopus gaudichaudii, Enyalius brasiliensis, Heterodactylus imbricatus, Placosoma glabellum, Taeniophallus affinis and Micrurus corallinus).
Thamnodynastes cf. nattereri, Tropidodryas striaticeps and Enyalius brasiliensis were the species considered very rare and Elapomorphus quinquelineatus, Sibynomorphus neuwiedi, Bothrops jararaca and Enyalius perditus were the species very common for the municipality of Juiz de Fora. Finally, in addition to providing data for biogeographic studies of Brazilian herpetofauna, the results documented here can be a source of information for policy makers to make decisions on environmental preservation measures and to help monitor the status of the diversity of reptile fauna in the region. 

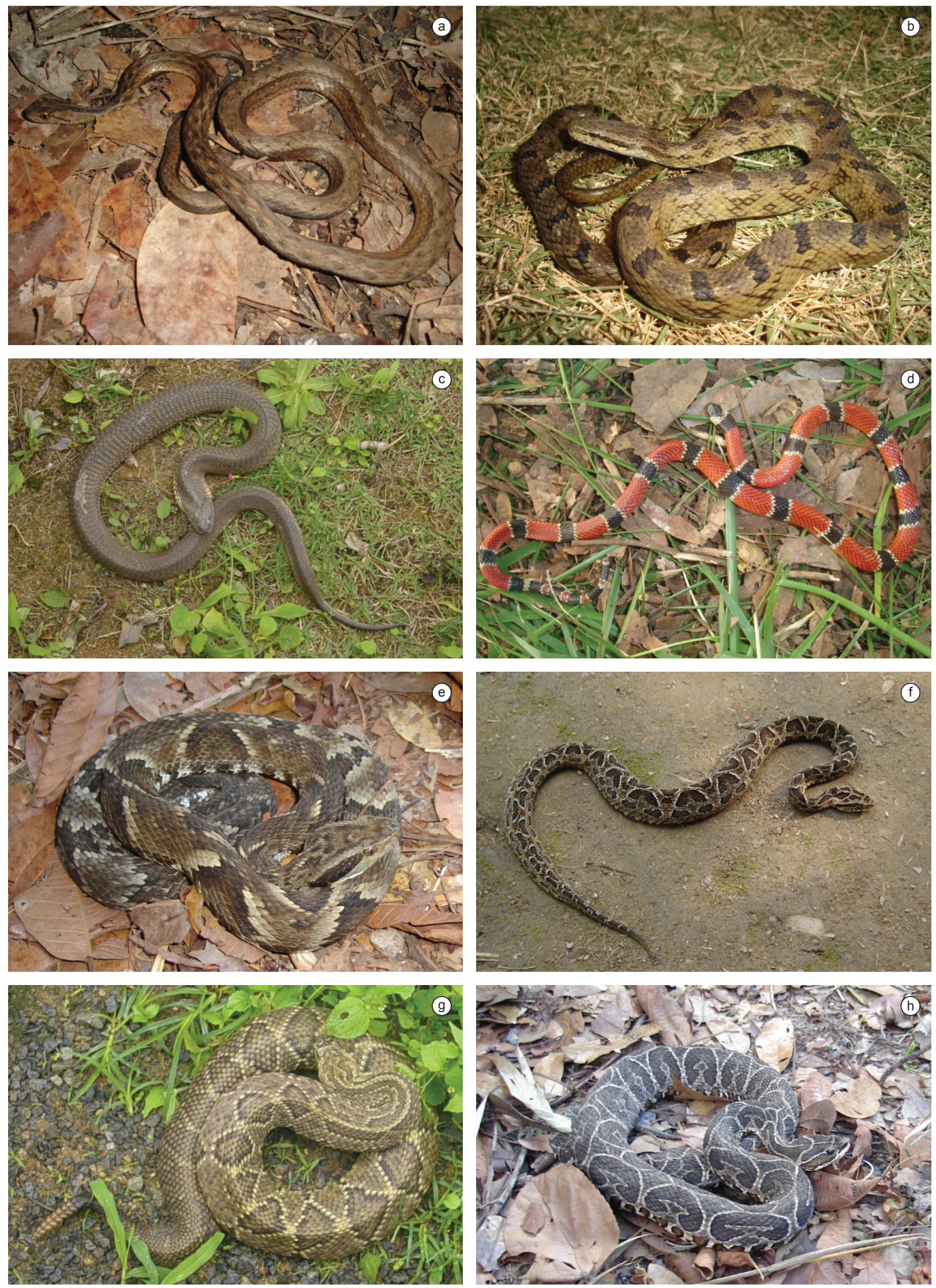

Figure 5. Some species of snakes recorded in the municipality of Juiz de Fora, Minas Gerais, southeastern Brazil. a) Thamnodynastes cf. nattereri; b) Tropidodryas striaticeps; c) Xenodon merremii; d) Micrurus corallinus; e) Bothrops jararaca; f) Bothrops neuwiedi; g) Crotalus durissus; and h) Bothrops alternatus.

Figura 5. Algumas espécies de répteis registradas no município de Juiz de Fora, Minas Gerais, sudeste do Brasil. a) Thamnodynastes cf. nattereri; b) Tropidodryas striaticeps; c) Xenodon merremii; d) Micrurus corallinus; e) Bothrops jararaca; f) Bothrops neuwiedi; g) Crotalus durissus; e h) Bothrops alternatus. 


\section{Acknowledgements}

We thank the Fundação de Amparo à Pesquisa do estado de Minas Gerais (FAPEMIG), the Conselho Nacional de Desenvolvimento Científico e Tecnológico (CNPq), Coordenação de Aperfeiçoamento de Pessoal de Nível Superior (CAPES) and Universidade Federal de Juiz de Fora (UFJF) for grants for scientific initiation and master's study and other financial support; the Agência de Gestão Ambiental de Juiz de Fora (AGENDA-JF) for permission to carry out the work in protected areas of the city (authorization 69995/08); the Sistema de Autorização e Informação em Biodiversidade (SISBIO) for permission to collect and transport specimens for this study (License no 17074-1); Comitê de Ética em Experimentação Animal da UFJF (Protocol 010/2008 - CEA); and the biologist Dr. Fabiano Matos Vieira for the preparation of photo plates.

\section{References}

ALBUQUERQUE, C.E. \& FERRAREZZI, H. 2004. A case of communal nesting in the Neotropical snake Sibynomorphus mikanii (Serpentes, Colubridae). Phyllomedusa 3(1):73-77.

ANDRADE, R.O. \& SILVANO, R.A.M. 1996. Comportamento alimentar e dieta da "falsa-coral" Oxyrhopus guibei Hoge \& Romano (Serpentes, Colubridae). Rev. Bras. Zool. 13(1):143-150.

ANTONINI, Y. \& DRUMMOND, G.M. 2006. Os estados da Mata Atlântica: Minas Gerais. In Mata Atlântica - uma rede pela floresta (M. Campanili \& M. Prochnow, eds.). RMA, Brasília, p.107-113. http://www.apremavi. org.br (último acesso em 8/03/2009).

ARAÚJO, A.F.B. 1987. Comportamento alimentar dos lagartos: o caso dos Tropidurus do grupo torquatus da Serra de Carajás, Pará (Sauria: Iguanidae). An. Etol. 5:189-197.

ARGÔLO, A.J.S. 2001. Oxyrhopus clathratus. Geographic Distribution. Herpetol. Rev. 32(1):61.

ARGÔLO, A.J.S. 2004. As Serpentes dos cacauais do Sudeste da Bahia. UESC, Ilhéus.

ARGÔLO, A.J.S. \& JORGE, A. 1999. Xenodon neuwiedii. Herpetol. Rev. 30(1):56.

ARGÔLO, A.J.S. \& FREITAS, M.A. 2002. Hydromedusa maximiliani. Herpetol. Rev. 33(2):147.

ASSIS, V.B. 1999. Introdução às serpentes da "Serra do Cipó" (municípios de Santana do Riacho e Jaboticatubas). Bios. 7(7):69-71.

ÁVILA-PIRES, T.C.S. 1995. Lizards of Brazilian Amazonia (Reptilia: Squamata). Zool. Verh. (Leiden) 299:1-706.

BARBO, F.E. 2008. Os Répteis no Município de São Paulo: aspectos históricos, diversidade e conservação. In Além do Concreto: contribuições para a proteção da biodiersidade paulistana (L.R. Malagoli, F.B. Bajestero \& M. Whately, eds). Instituto Socioambiental, São Paulo, p.234-267.

BASTOS, E.G.M., ARAÚJO, A.F.B. \& SILVA, H.R. 2005. Records of the Rattlesnake Crotalus durissus terrificus (Laurenti) (Serpentes, Viperidae) in the State of Rio de Janeiro, Brazil: A possible case of invasion facilitated by deforestation. Rev. Bras. Zool. 22(3):812-815. http://dx.doi. org/10.1590/S0101-81752005000300047

BÉRNILS, R.S. \& COSTA, H.C. 2011. Brazilian reptiles - List of species. http://www.sbherpetologia.org.br (último acesso em 30/05/2012).

BERNILS, R.S., NOGUEIRA, C.C. \& XAVIER-DA-SILVA, V. 2009. Répteis. In Biota Minas: diagnóstico do conhecimento sobre a biodiversidade no Estado de Minas Gerais (G.M. Drummond, C.S. Martins, M.B. Greco \& F. Vieira, eds.). Fundação Biodiversitas, Belo Horizonte, p.251-278.

BERTOLUCI, J. 1998. Serpentes. In Livro Vermelho das Espécies Ameaçadas de Extinção da Fauna de Minas Gerais (A.B.M. Machado, G.A. Fonseca, L.M.S. Aguiar \& L.V. Lins, eds.). Fundação Biodiversitas, Belo Horizonte, p.417.
BERTOLUCI, J., CANELAS, M.A.S., EISEMBERG, C.C., PALMUTI, C.F.S. \& MONTINGELLI, G.G. 2009. Herpetofauna da Estação Ambiental de Peti, um fragmento de Mata Atlântica do estado de Minas Gerais, sudeste do Brasil. Biota Neotrop. 9(1): http://www.biotaneotropica.org.br/v9n1/ en/abstract?inventory+bn01409012009. (último acesso em 10/12/2010).

BRITES, V.L.C. \& BAUAB, F.A. 1988. Fauna ofidiana do município de Uberlândia, Minas Gerais - Brasil. I. Ocorrência na área urbana. Rev. Centro Ciênc. Biom. Univ. Fed. Uberl. 4(1):3-8.

CAMPBELL, J.A. \& LAMAR, W.W. 2004. The Venomous Reptiles of the Western Hemisphere. Cornell University Press, Ithaca.

CARRANZA, S. \& ARNOLD, E.N. 2006. Systematics, biogeography, and evolution of Hemidactylus geckos (Reptilia: Gekkonidae) elucidated using mitochondrial DNA sequences. Mol. Phylogenet. Evol. 38:531-545. http://dx.doi.org/10.1016/j.ympev.2005.07.012

CARRASCO, P.A., MATTONI, C.I., LEYNAUD, G.C. \& SCROCCHI, G.J. 2012. Morphology, phylogeny and taxonomy of South American bothropoid pitvipers (Serpentes, Viperidae). Zool. Scr. 41:109-124. http:// dx.doi.org/10.1111/j.1463-6409.2011.00511.x

CICCHI, P.J.P., SENA, M.A., PECCININI-SEALE, D.M \& DUARTE, M.R. 2007. Snakes From Coastal Islands Of State Of São Paulo, Southeastern Brazil. Biota Neotrop. 7(2): http://www.biotaneotropica. org.br/v7n2/pt/abstract?inventory+bn03907022007 (último acesso em 10/09/2009).

CONDEZ, T.H., SAWAYA, R.J. \& DIXO, M. 2009. Herpetofauna dos remanescentes de Mata Atlântica da região de Tapiraí e Piedade, SP, sudeste do Brasil. Biota Neotrop. 9(1): http://www.biotaneotropica. org.br/v9n1/en/abstract?inventory+bn01809012009 (último acesso em 6/07/2009).

COSTA, H.C., FERNANDES, V.D., RODRIGUES, A.C. \& FEIO, R.N. 2009. Lizards and Amphisbaenians, municipality of Viçosa, state of Minas Gerais, southeastern Brazil. CheckList 5(3):732-745.

COSTA, H.C., PANTOJA, D.L., PONTES, J.L. \& FEIO, R.N. 2010. Serpentes do município de Viçosa, Mata Atlântica do Sudeste do Brasil. Biota Neotrop. 10(3): http://www.biotaneotropica.org.br/v10n3/en/abstract?i nventory+bn03610032010 (último acesso em 5/01/2011).

CUNHA, O.R. \& NASCIMENTO, F.P. 1978. Ofídios da Amazônia X - As cobras da região Leste do Pará. Publ. Av. Museu Paraense Emílio Goeldi 31:1-218.

CURCIO, F.F. 2008. Revisão Taxonômica e variação geográfica do gênero Erythrolamprus Boie, 1826 (Serpentes, Xenodontinae). Tese de doutorado, Universidade de São Paulo, São Paulo.

CURCIO, F.F., PIACENTINI, V.Q. \& FERNANDES, D. 2009. On the status of the snake genera Erythrolamprus Boie, Liophis Wagler and Lygophis Fitzinger (Serpentes, Xenodontinae). Zootaxa 2173:66-68.

DI-BERNARDO, M. 1992. Revalidation of the genus Echinanthera Cope, 1894 and its conceptual amplification (Serpentes, Colubridae). Com. Mu. Ciên. PUCRS, Ser. Zoo. 5(13):225-256.

DIXO, M. \& METZGER, J.P. 2009. Are corridors, fragment size and forest structure important for the conservation of leaf-litter lizards in a fragmented landscape? Oryx 43(3):435-442. http://dx.doi.org/10.1017/ S0030605309431508

DIXON, J.R. 1989. A Key and Checklist of the Neotropical Snake Genus Liophis with Country List and Maps. Smithsonian Herpetol. Ser. 79:1-40.

DIXON, J.R., WIEST, J.A. \& CEI, J.M. 1993. Revision of the tropical snake Chironius Fitzinger (Serpentes, Colubridae). Mus. Reg. Sci. Nat. 13:1-279.

DRUMMOND, G.M., MARTINS, C.S., MACHADO, A.B.M., SEBAIO, F.A. \& ANTONINI, Y. 2005. Biodiversidade em Minas Gerais: Um Atlas para sua conservação. 2. ed. Fundação Biodiversitas, Belo Horizonte.

DRUMMOND, G.M., GRECO, M.B. \& VIEIRA, F. 2009. Introdução - Biodiversidade em Minas Gerais. In Biota Minas: diagnóstico do conhecimento sobre a biodiversidade no Estado de Minas Gerais (G.M. Drummond, C.S. Martins, M.B. Greco \& F. Vieira, eds.). Fundação Biodiversitas, Belo Horizonte, p.22-28. 
ERNST, C.H. \& BARBOUR, R.W. 1989. Turtles of the World. Smithsonian Institution Press, Washington.

ETHERIDGE, R. \& WILLIAMS, E.E. 1991. A review of South American lizard genera Urostrophus and Anisoleps (Squamata: Iguania: Polychridae). Bull. Mus. Comp. Zool. 152(5):317-361.

FEIO, R.N. \& CARAMASCHI, U. 2002. Contribuição ao conhecimento da herpetofauna do nordeste do estado de Minas Gerais, Brasil. Phyllomedusa 1(2):105-111.

FENWICK, A.M., GUTBERLET-JUNIOR, R.L., EVANS, J.A. \& PARKINSON, C.L. 2009. Morphological and molecular evidence for phylogeny and classification of South American pitvipers, genera Bothrops, Bothriopsis, and Bothrocophias (Serpentes: Viperidae). Zoo. J. Linn. Soc. 156(3):617-640. http://dx.doi.org/10.1111/j.10963642.2008.00495.x

FERRAREZZI, H., 1993. Sistemática filogenética de Elapomorphus, Phalotris e Apostolepis (Serpentes, Colubridae, Xenodontinae). Dissertação de Mestrado, Universidade de São Paulo, São Paulo.

FONSECA, G.A.B. 1985. The vanishing Brazilian Atlantic Forest. Biol Conserv. 34:17-34. http://dx.doi.org/10.1016/0006-3207(85)90055-2

FORLANI, M.C., BERNARDO, P.H., HADDAD, C.F.B. \& ZAHER, H. 2010. Herpetofauna do Parque Estadual Carlos Botelho, São Paulo, Brasil. Biota Neotrop. 10(3): http://www.biotaneotropica.org.br/v10n3/en/abstract?in ventory+bn00210032010 (último acesso em 16/03/2011)

FRANÇA, F.G.R., MESQUITA, D.O., NOGUEIRA, C.C. \& ARAÚJO, A.F.B. 2008. Phylogeny and Ecology Determine Morphological Structure in a Snake Assemblage in the Central Brazilian Cerrado. Copeia 1:23-38.

FRANCO, F.L. 1994. O gênero Sibynomorphus Fitzinger, 1843 no Brasil (Colubridae: Xenodontinae, Dipsadini). Dissertação de mestrado. Pontifícia Universidade Católica do Rio Grande do Sul, Porto Alegre.

FRANCO, F.L. \& FERREIRA, T.G. 2002. Descrição de uma nova espécie de Tamnodynastes Wagler, 1830 (Serpentes, Colubridae) do nordeste brasileiro, com comentários sobre o gênero. Phyllomedusa 1:57-74.

FRANCO, F.L. \& FERREIRA, T.G. 2003. Ocorrência de Tamnodynastes strigatus Wagler, 1830 (Serpentes, Colubridae) nos escudos das Guianas, estados do Pará e Roraima, Brasil. Phyllomedusa 2(2):117-119.

FREIRE, E.M.X. 1999. Geographic Distribution: Oxyrhopus guibei. Herpetol. Rev. 30(1):55.

FREIRE, E.M.X. \& SILVA, S.M.T. 2000. Geographic Distribution: Taeniophallus affinis. Herpetol. Rev. 31(3):187.

FUNDAÇÃO SOS MATAATLÂNTICA. 2011. Acesso às Informações do Atlas dos Remanescentes Florestais. http://mapas.sosma.org.br/site_media/ download/estatisticas/lista_municipios_desflorestamento_2008-2010. pdf (último acesso em 30/05/2012).

GOMIDES, S.C., RIOS, C.H.V., OUVERNEY JR., W.L., SOUSA, B.M. \& BRESCOVIT, A.D. 2010. Enyalius perditus $(\mathrm{NCN})$ and Enyalius bilineatus (NCN). Predation. Herpetol. Rev. 41(2):221-222.

GOMIDES, S.C. \& SOUSA, B.M. In press. Herpetofauna da Serra do Relógio, Minas Gerais, sudeste do Brasil. Rev. Bras. Zoocienc.

GUEDES, T.B. \& MARQUES, O.A.V. 2011. Reptilia, Squamata, Serpentes, Dipsadidae, Tropidodryas striaticeps (Cope, 1869): Latitudinal and altitudinal extension and geographic distribution map. CheckList 7(1):78-82.

HARTMANN, P.A. \& MARQUES, O.A.V. 2005. Diet and habitat use of two sympatric species of Philodryas (Colubridae), in South Brazil. AmphibiaReptilia 26(1):25-31. http://dx.doi.org/10.1163/1568538053693251

HOGE, A.R. \& ROMANO, S.A.R.W.L. 1976. Description of a new species of Oxyrhopus Wagler (Serpentes, Colubridae). Mem. I. Butantan 40:55-62.

HOSER, R. 2009. A reclassification of the Rattlesnakes; species formerly exclusively referred to the Genera Crotalus and Sistrurus. Aust. J. Herpetol. 6:1-21.

INSTITUTO NACIONAL DE PESQUISAS ESPACIAIS - INPE. 2012. Notícias: INPE e SOS Mata Atlântica divulgam novos dados do Atlas. http://www.inpe.br/noticias/noticia.php?Cod_Noticia=2923 (último acesso em 29/05/2012).
INTERNATIONAL UNION FOR CONSERVATION OF NATURE - IUCN. 2011. IUCN Red List of Threatened Species. v. 2010.2. http://www.iucnredlist.org (last access on 13/04/2011).

JACKSON, J.F. 1978. Differentiation in the genera Enyalius and Strobilurus (Iguanidae): implications for pleistocene climatic changes in eastern Brazil. Arq. Zool. 30(1):1-79.

JUIZ DE FORA. Prefeitura Municipal. Plano Diretor/JF-IPPLAN/ JF - Anuário. 2004. Clima de Juiz de Fora. http://www.pjf.mg.gov.br/ acidade/clima.htm (último acesso em 14/05/2006).

KAWASHITA-RIBEIRO, R.A. 2007. História natural de uma taxocenose de serpentes da RPPN Acurizal e áreas adjacentes, Serra do Amolar, borda Oeste do Pantanal, Corumbá, Mato Grosso do Sul, Brasil. Dissertação de mestrado, Universidade Federal do Mato Grosso, Cuiabá.

KREBS, C.J. 1999. Ecological methodology. Addison-Wesley Educational Publishers, California.

LEMA, T. 1987. Lista preliminar das serpentes registradas para o Estado do Rio Grande do Sul (Brasil Meridional) (Reptilia, Lepidosauria, Squamata). Acta Biol. Leopold. 9:225-240.

LEMA, T. 1992. Presença de Elapomorphus quinquelineatus (Raddi) no extremo sul do Brasil e a ocorrência de rara anomalia (Serpentes, Colubridae, Xenodontinae, Elapomorphini). Comun. Mus. Cienc. PUCRS 5(1):01-07.

LEMA, T. \& M. T. S. FERREIRA. 1990. Contribuição ao conhecimento dos Testudines do Rio Grande do Sul (Brasil): Lista sistemática comentada (Reptilia). Acta Biol. Leopold. 12:125-164.

LOEBMANN, D. 2008 Geographic Distribution: Echinanthera affinis (Günther's forest snake). Herpetol. Rev. 39(2):241.

MAGURRAN, A. 1988. Ecological diversity and its measurement. Princeton University Press, Princeton.

MARQUES, O.A.V. 1996. Biologia reprodutiva da cobra-coral Erythrolamprus aesculapii Linnaeus (Colubridae), no sudeste do Brasil. Rev. Bras. Zool. 13(3):747-753. http://dx.doi.org/10.1590/S010181751996000300022

MARQUES, O.A.V. \& SAZIMA, I. 2004. História natural dos répteis da Estação Ecológica Juréia-Itatins. In Estação Ecológica Juréia-Itatins: ambiente físico, flora e fauna (O.A.V. Marques \& W. Duleba, eds.). Holos, Ribeirão Preto, p.257-277.

MARQUES, O.A.V. \& SOUZA, V.C. 1993. Nota sobre a atividade alimentar de Liophis miliaris no ambiente marinho (Serpentes, Colubridae). Rev. Bras. Biol. 53:645-648.

MARQUES, O.A.V., ABE, A.S. \& MARTINS, M. 1998. Estudo diagnóstico da diversidade de répteis do Estado de São Paulo. In Biodiversidade do Estado de São Paulo, Brasil: síntese do conhecimento ao final do século XX (R.M.C Castro, ed.). Editora Fapesp, São Paulo, p. 27-38.

MARQUES, O.A.V., ETEROVIC, A. \& SAZIMA, I. 2001. Serpentes da Mata Atlântica. Guia ilustrado para a Serra do Mar. Holos, Ribeirão Preto.

MARQUES, O.A.V., PEREIRA, D.N., BARBO, F.E., GERMANO, V.J. \& SAWAYA, R.J. 2009. Os Répteis do Município de São Paulo: diversidade e ecologia da fauna pretérita e atual. Biota Neotrop. 9(2): http://www. biotaneotropica.org.br/v9n2/en/abstract?article+bn02309022009 (último acesso em 22/06/2010).

MARTINS, M. 1998. Revisão Taxonômica e sistemática filogenética do gênero Ophiodes Wagler, 1828 (Sauria, Anguidae, Diploglossinae). Doctoral Dissertation, Pontifícia Universidade Católica do Rio Grande de Sul, Porto Alegre.

MARTINS, M., ARAÚJO, M.S., SAWAYA, R.J. \& NUNES, R. 2001. Diversity and evolution of macrohabitat use body size and morphology in a monophyletic group of neotropical pitvipers (Bothrops). J. Zool. 254(4):529-538. http://dx.doi.org/10.1017/S0952836901001030

McCORD, W.P., JOSEPH-OUNI, M. \& LAMAR, W.W. 2001. Taxonomic reevaluation of Phrynops (Testudines: Chelidae) with the description of two new genera and a new species of Batrachemys. Rev. Biol. Trop. 49:715-764. 
MESQUITA, D.O. \& BRITES, V.L.C. 2003. Aspectos taxonômicos e ecológicos de uma população de Bothrops alternatus Duméril, Bibron \& Duméril, 1854 (Serpentes, Viperidae) das regiões do triângulo e Alto Paranaíba, Minas Gerais. São Cristóvão 3(2):33-38.

MIERES, M.M. \& FITZGERALD L.A. 2006. Monitoring and Managing the Harvest of Tegu Lizards in Paraguay. J. Wildl. Manag. 70(6):1723-1734. http://dx.doi.org/10.2193/0022-541X(2006)70[1723:MAMTHO]2.0. $\mathrm{CO} ; 2$

MITTERMEIER, R.A., GIL, P.R., HOFMANN, M., PILGRIM, J., BROOKS, T., MITTERMEIER, C.G., LAMOREAUX, J. \& FONSECA, G.A.B. 2004. Hotspots revisited: Earth's biologically richest and most endangered terrestrial ecoregions. Cemex, Washington.

MORATO, S.A.A. 1995. Padrões de distribuição da fauna de serpentes da floresta de araucária e ecossistemas associados da região sul do Brasil. Dissertação de mestrado, Universidade Federal do Paraná, Curitiba.

MORATO, S.A.A. 2005. Serpentes da Região Atlântica do Estado do Paraná, Brasil: diversidade, distribuição e ecologia. Tese de doutorado, Universidade Federal do Paraná, Curitiba.

MYERS, N., MITTERMEIER, R.A., MITTERMEIER, C.G., FONSECA, G.A.B. \& KENT. J. 2000. Biodiversity hotspots for conservation priorities. Nature 403:853-858. http://dx.doi.org/10.1038/35002501

NOGUEIRA, C.C. 2001. New records of Squamate Reptiles in Central Brazilian Cerrado II: Brasília Region. Herpetol. Rev. 32(4):285-287.

NOGUEIRA, C., RIBEIRO, S.R., COSTA, G.C. \& COLLI, G.R. 2011. Vicariance and endemism in a Neotropical savanna hotspot: distribution patterns of Cerrado squamate reptiles. J. Biogeogr. 38:1907-1922. http:// dx.doi.org/10.1111/j.1365-2699.2011.02538.x

NORMAN, D.R. \& NAYLOR, L. 1994. Amphibians and Reptiles of the Paraguayan Chaco. C. R. Edited by the author, San Jose, v.1.

NOVELLI, I.A. \& SOUSA, B.M. 2007. Análise descritiva do comportamento de corte e cópula de Hydromedusa maximiliani (Mikan, 1820) (Testudines, Chelidae) em laboratório. Rev. Bras. Zooc. 9:49-56.

NOVELLI, I.A., LUCAS, P.S. \& SANTOS, R.C. 2011. Reptilia, Squamata, Gymnophthalmidae, Heterodactylus imbricatus Spix, 1825: Filling gaps in the state of Minas Gerais. Check List 7(1):30-31.

PALMUTI, C.F.S., CASSIMIRO, J. \& BERTOLUCI, J. 2009. Food habits of snakes from the RPPN Feliciano Miguel Abdala, an Atlantic Forest fragment of southeastern Brazil. Biota Neotrop. 9(1): http://www.biotaneotropica. org.br/v9n1/en/abstract?short-communication+bn02209012009 (último acesso em 26/11/2010).

PEREZ, R. \& RIBEIRO, S.L.B. 2008. Reptilia, Squamata, Amphisbaenidae, Leposternon spp.: Distribution extension, new state record, and geographic distribution map. CheckList 4(3):291-294.

PETERS, J.A. \& DONOSO-BARROS, R. 1986. Catalogue of the neotropical squamata: Part II - lizards and amphisbaenians. with new material by P. E. VANZOLINI. Smithsonian Institution Press, Washington, p.1-297.

PETERS, J.A. \& OREJAS-MIRANDA, B. 1986. Catalogue of the neotropical squamata: Part I - Snakes. with new material by P. E. VANZOLINI. Smithsonian Institution, Washington, p.1-347.

PIFANO, D.S., VALENTE, A.S.M., CASTRO, R.M., PIVARI, M.O.D., SALIMENA, F.R.G. \& OLIVEIRA-FILHO, A.T. 2007. Similaridade entre os hábitats da vegetação do morro do Imperador, Juiz de Fora, Minas Gerais, com base na composição da sua flora fanerogâmica. Rodriguésia 58(4):885-904.

PONTES, J.A.L. \& ROCHA, C.F.D. 2008. Serpentes da Serra do Mendanha, Rio de Janeiro, RJ: ecologia e conservação. Technical Books, Rio de Janeiro.

PUORTO, G. \& FRANÇA, F.O.S. 2003. Serpentes não-peçonhentas e aspectos clínicos dos acidentes. In Animais Peçonhentos no Brasil: Biologia, Clínica e Terapêutica dos Acidentes (J.L.C. Cardoso, F.O.S. França, F.H. Wen, C.M.S. Málaque \& V. Haddad Junior, eds.). SARVIER/FAPESP, São Paulo, p.108-114.
RECODER, R. \& NOGUEIRA, C. 2007. Composição e diversidade de répteis na região sul do Parque Nacional Grande Sertão Veredas, Brasil Central. Biota Neotrop. 7(3):267-278: http://www.biotaneotropica.org.br/v7n3/ pt/abstract?inventory+bn01107032007 (último acesso em 23/07/2008).

RIBEIRO, L.B. \& SOUSA, B.M. 2006. Urostrophus vautieri (NCN). Skin shedding. Herpetol. Rev. 37(3):348.

RIBEIRO, L.B., GOMIDES, S.C., SANTOS, A.O. \& SOUSA, B.M. 2008. Thermoregulatory behavior of the saxicolous lizard, Tropidurus torquatus (Squamata: Tropiduridae), in a rocky outcrop in Minas Gerais, Brazil. Herpetol. Conserv. Biol. 3(1):63-70.

RIBEIRO, L.B., SOUSA, B.M. \& GOMIDES, S.C. 2009a. Range structure, microhabitat use, and activity patterns of the saxicolous lizard Tropidurus torquatus (Tropiduridae) on a rock outcrop in Minas Gerais, Brazil. Rev. Chil. Hist. Nat. 82:577-588. http://dx.doi.org/10.4067/S0716078X2009000400011

RIBEIRO, M.C., METZGER, J.P., MARTENSEN A.C., PONZONI F.J. \& HIROTA, M.M. 2009b. The Brazilian Atlantic Forest: How much is left, and how is the remaining forest distributed? Implications for conservation. Biol. Conserv. 142:1141-1153. http://dx.doi.org/10.1016/j. biocon.2009.02.021

RIBEIRO, S., NOGUEIRA, C., CINTRA, C.E.D., SILVA JUNIOR, N.J. \& ZAHER, H. 2011. Description of a New Pored Leposternon (Squamata, Amphisbaenidae) from the Brazilian Cerrado. South American J. Herpetol. 6(3):177-188. http://dx.doi.org/10.2994/057.006.0303

RIBON, R., SIMON, J.E. \& MATTOS, G.T. 2003. Bird extinctions in Atlantic forest fragments of the Viçosa region, Southeastern Brazil. Conserv. Biol. 17(6):1827-1839. http://dx.doi.org/10.1111/j.15231739.2003.00377.x

ROCHA, C.F.D. 2000. Biogeografia de répteis de restingas: distribuição, ocorrência e endemismos. Pp. 99-116. Em: Ecologia de Restingas e Lagoas Costeiras. F.A. Esteves \& L.D. Lacerda (eds.). NUPEM/UFRJ, Macaé, Rio de Janeiro, Brasil.

RODRIGUES, M.T. 1987. Sistemática, ecologia e zoogeografia dos Tropidurus do grupo torquatus ao Sul do Rio Amazonas (Sauria, Iguanidae). Arq. Zool. 31(3):105-230.

RODRIGUES, M.T. 2005. The conservation of Brazilian reptiles: challenges for a megadiverse country. Conserv. Biol. 19:659-664. http://dx.doi. org/10.1111/j.1523-1739.2005.00690.x

ROMESBURG, H.C. 1984. Cluster analysis for researches. Robert E. Krieger Publishing Company, Florida.

ROZE, J.A. 1996. Coral Snakes of the Americas. Krieger, Florida.

SANTOS, R.C., LUCAS, P.S., SOUSA, B.M. \& NOVELLI, I.A. 2009. Reptilia, Squamata, Leiosauridae, Urostrophus vautieri: Distribution extension and geographic distribution map. CheckList 5(3):533-536.

SÃO PEDRO, V.A. \& PIRES, M.R. 2009. As Serpentes da Região de Ouro Branco, extremo sul da Cadeia do Espinhaço, Minas Gerais. Rev. Ceres 56(2):166-171.

SAWAYA, R.J., MARQUES, O.A.V. \& MARTINS, M. 2008. Composição e história natural das serpentes de Cerrado de Itirapina, São Paulo, Sudeste do Brasil. Biota Neotrop. 3(2): http://www.biotaneotropica.org.br/v8n2/ en/abstract?inventory+bn01308022008 (último acesso em 07/03/2009).

SAZIMA, I. 2001. Répteis. In Intervales: fundação para a conservação e produção florestal do Estado de São Paulo (C. Leonel, ed.). Fundação Florestal, São Paulo, p.148-158.

SAZIMA, I. \& HADDAD, C.F.B. 1992. Répteis da Serra do Japi: notas sobre história natural. In História natural da Serra do Japi: ecologia e preservação de uma área florestal do Sudeste do Brasil (L.P.C. Morellato, org.). UNICAMP/FAPESP, Campinas, p.212-236.

SAZIMA, I. \& PUORTO, G. 1993. Feeding technique of juvenile Tropidodryas striaticeps: probable caudal luring in a colubrid snake. Copeia 1993(1):222-226. http://dx.doi.org/10.2307/1446315

SCHARGEL, W.E., FUENMAYOR, G.R. \& MYERS, C.W. 2005. An Enigmatic New Snake from Cloud Forest of the PenínSula de Paria, Venezuela (Colubridae: Genus Taeniophallus?). Amer. Mus. Novit. 3484:1-22. http://dx.doi.org/10.1206/0003-0082(2005)484[0001:AENSFC]2.0.CO;2 
SILVA, V.X. \& RODRIGUES, M.T. 2008. Taxonomic revision of the Bothrops neuwiedi complex (Serpentes, Viperidae) with description of a new species. Phyllomedusa 7(1):45-90.

SOUSA, B.M. \& CRUZ, C.A.G. 2008. Hábitos alimentares de Enyalius perditus (Squamata, Leiosauridae) no Parque Estadual do Ibitipoca, Minas Gerais, Brasil. Iheringia 98(2):260-265. http://dx.doi.org/10.1590/ S0073-47212008000200015

SOUSA, B.M., NASCIMENTO, A.E.R., GOMIDES, S.C., VARELA RIOS, C.H., HUDSON, A.H. \& NOVELLI, I.A. 2010. Répteis em fragmentos de Cerrado e Mata Atlântica do Campo das Vertentes, Estado de Minas Gerais, Sudeste do Brasil. Biota Neotrop. 10(2): http://www. biotaneotropica.org.br/v10n2/en/abstract?article+bn03510022010 (último acesso em 12/12/2010).

SOUZA, F.L. 2004. Hydromedusa maximiliani: The Brazilian snakenecked turtle. Reptilia 40:47-51.

SOUZA, F.L. \& ABE A.S. 2001. Population structure and reproductive aspects of the freshwater turtle, Phrynops geoffroanus, inhabiting an urban river in southeastern Brazil. Stud. Neotrop. Fauna Environ. 36(1):57-62. http:// dx.doi.org/10.1076/snfe.36.1.57.8887

SOUZA, F.L., CUNHA, A.F., OLIVEIRA, M.A., PEREIRA, G.A.G. \& REIS, S.F. 2003. Preliminary phylogeographic analysis of the neotropical freshwater turtle Hydromedusa maximiliani (Chelidae). J. Herpetol. 37(2):427-433. http://dx.doi.org/10.1670/00221511(2003)037[0427:PPAOTN]2.0.CO;2

STENDER-OLIVEIRA, F. 2008. Ecologia alimentar e reprodutiva de duas espécies de Tropidodryas (Serpentes, Colubridae) da Mata Atlântica. Dissertação de Mestrado, Universidade de São Paulo, São Paulo.

TEIXEIRA, R.L., ROLDI, K. \& VRCIBRADIC, D. 2005. Ecological Comparisons between the Sympatric Lizards Enyalius bilineatus and Enyalius brasiliensis (Iguanidae, Leiosaurinae) from an Atlantic RainForest Area in Southeastern Brazil. J. Herpetol. 39(3):504-509. http:// dx.doi.org/10.1670/9-05N.1

THOMAS, R.A. 1976. A Revision of the South American colubrid snake genus Philodryas Wagler, 1890. Doctoral Thesis, Texas A. \& M. University.

THOMAS, R.A. \& DIXON, J.A. 1977. A new systematic arrangement for Philodryas serra (Schlegel) and Philodryas pseudoserra Amaral (Serpentes: Colubridae). Pearce Sellards Ser. 27:1-20.

UETZ, P. \& HALLERMANN, J. 2011. The EMBL reptile database. http:// www.reptile-database.org. (último acesso em 30/06/2011).
UZZELL JUNIOR, T.M. 1959. Teiid lizards of the genus Placosoma. Occas. Pap. Mus. Zool. Univ. Mich. 606:1-15.

UZZELL JUNIOR, T.M. 1969. The status of the genera Ecpleopus, Arthroseps and Aspidolaemus (Sauria, Teiidae). Postilla 135:1-23.

VAN SLUYS, M., FERREIRA, V.M. \& ROCHA, C.F.D. 2004. Natural history of the lizard Enyalius brasiliensis (Lesson, 1828) (Leiosauridae) from an Atlantic Forest of southeastern Brazil. Braz. J. Biol. 64:353-356. http:// dx.doi.org/10.1590/S1519-69842004000200021

VANZOLINI, P. E. 2002. An aid to the identification of the South American species of Amphisbaena (Squamata, Amphisbaenidae). Pap. Avulsos Zool. (São Paulo) 42(15):351-362.

VANZOLINI, P.E., RAMOS-COSTA, A.M.M. \& VITT, L.J. 1980. Répteis das Caatingas. Academia Brasileira de Ciências, Rio de Janeiro.

VIDAL, N., DEWYNTER, M. \& GOWER, D.J. 2010. Dissecting the major American snake radiation: a molecular phylogeny of the Dipsadidae Bonaparte (Serpentes, Caenophidia). C.R. Biolog. 333:48-55. http:// dx.doi.org/10.1016/j.crvi.2009.11.003

VRCIBRADIC, D., ALMEIDA-GOMES, M., BORGES-JUNIOR, V.N.T., KIEFER, M.C., VAN SLUYS, M. \& ROCHA, C.F.D. 2006. Reptilia, Scincidae, Mabuy a frenata: Distribution extension. CheckList 2(2):57-58

WÜSTER, W., SALOMÃO, M.G., QUIJADA-MASCAREÑAS, J.A., THORPE, R.S. \& BBBSP. 2002. Origins and evolution of the South American pitviper fauna: evidence from mitochondrial DNA sequence analysis. In Biology of the vipers (G.W. Schuett, M. Höggren, M.E. Douglas \& H.W. Greene, eds.). Eagle Mountain Publishing, Eagle Mountain, p.111-128.

WÜSTER, W., FERGUSON, J.E., QUIJADA-MASCAREÑAS, J.A., POOK, C.E., SALOMÃO, M.G. \& THORPE, R.S. 2005. Tracing an invasion: landbridges, refugia, and the phylogeography of the Neotropical rattlesnake (Serpentes: Viperida: Crotalus durissus). Mol. Ecol. 14:1095-1108. http://dx.doi.org/10.1111/j.1365-294X.2005.02471.x

ZAHER, H., GRAZZIOTIN, F.G., CADLE, J.E, MURPHY, R.W., MOURALEITE, J.C. \& BONATTO, S.L. 2009. Molecular phylogeny of advanced snakes (Serpentes, Caenophidia) with an emphasis on South American Xenodontines: a revised classification and descriptions of new taxa. Pap. Av. Zool. 49(11):115-153. http://dx.doi.org/10.1590/S003110492009001100001

ZATZ, M.G. 2002. O polimorfismo cromático e sua manutenção em Enyalius sp. (Squamata: Leiosauridae) no Cerrado do Brasil Central. Dissertação de Mestrado, Universidade de Brasília, Brasília. 